\section{THE HEAVENS FOR NOVEMBER.}

The right ascension of the sun on November 1 is 14 h. $28 \mathrm{~m} .40 \mathrm{~s}$. and its declination south $14 \mathrm{deg} .41 \mathrm{~m}$. $15 \mathrm{~s}$

The right ascension of the sun on November 30 is

October the sun's isk has been quite clear from spots, but although in the minimum tage of sun spot activity, it will pay to keep watch for developments of, for the time, unusual character. MERCURY.

Mercury is morning star at the opening of the month. On November 7, at 12 hours, however, Mercury comes into superior conjunction with the sun and changes to evening star:

On November 8 , at 8 hours, Mercury is at its descend ing node.

On November 12 , at 2 hours, Mercury is in conjunc-
ion with Mars, with Mercury 22 minutes of are south of Mars.

On November 16 , at 7 hours, Mercury will be in con junction with Uranus, when Mercury will be 1 deg. $4 \mathrm{~m}$. south of Uranus.

On November 18, at 1 hour, Mercury will be in aphelion, or in that part of its orbit most distant from the

On the same date, at 7 hours, Mercury will be in conjunction with Saturn, when Mercury will be 2 deg. 54 in. south of Saturn.

A conjunction of Mercury and the moon occurs on November 24, at $8 \mathrm{~h}$. $31 \mathrm{ml}$., when Mercury will be deg. north of the moon.

The right ascension of Mercury on the fifteenth of the month is $15 \mathrm{~h} .42 \mathrm{~m} 11 \mathrm{~s}$. and its declination south $20 \mathrm{deg} .29 \mathrm{~m} .8 \mathrm{~s}$

\section{VENUS.}

Venus is morning star, and is still the most brilliant object in the eastern morning sky.

The interesting conjunction of Venus and Jupiter in October we trust was observed by many readers of these notes. The very marked brilliancy of heliocentric latitude north.

On November 22 at $9 \mathrm{~h}$. $29 \mathrm{~m}$, Venus will be in eonjnnetion with the moon, when the planet will be 6 deg. $39 \mathrm{~m}$. north of the moon.

On the first of the month Venus rises at $4 \mathrm{~h} .23 \mathrm{~m}$. and crosses the meridian at $10 \mathrm{~h} .10 \mathrm{~m} . \mathrm{A}$. M

On the last of the month Venus rises at $5 \mathrm{~h} .35 \mathrm{~m}$. and crosses the meridian at $10 \mathrm{~h} .34 \mathrm{~m}$. A. M.

The right ascension of Venus on the fifteenth day of 10 deg. $59 \mathrm{~m} .18 \mathrm{~s}$.

Mars is evening star until November 21, on which date, at 7 hours, it comes into conjunction with the sun and changes to morning star.

On Novernber 21, at 4 hours, Mars is in conjunction with Uranus, when Mars will be 24 minutes of are south of Uranus.

On November 24 , at $4 \mathrm{~h} .9 \mathrm{~m}$., Mars and the moon will be in conjunction, with Mars 4 eg. $4 \mathrm{~m}$. north of the

On November 27, at 1 hour, Mars will be in conjunetion with Saturn, when Mars will be 2 deg. $2 \mathrm{~m}$. south of Saturn.

On the first of the month Mars crosses the meridian at 7 minutes past noon, and sets at $5 \mathrm{~h} .8 \mathrm{~m}$. P. M. On the last of the month Mars rises at $6 \mathrm{~h} .56 \mathrm{~m}$. A. and crosses the meridian at $11 \mathrm{~h} .38 \mathrm{~m}$. A. M. The right ascension of Mars on the fifteenth day of
the month is 15 h. $31 \mathrm{~m} .18 \mathrm{~s}$. and its declination south 19 deg. $13 \mathrm{~m} .25 \mathrm{~s}$. JUPITER.

Jupiter is morning star, and slowly coming into position for telescopic observation, although still at a rather low altitude at dawn.

On November 20 , at 10 h. $52 \mathrm{~m}$., Jupiter is in conjunction with the moon, with the planet 6 deg. $24 \mathrm{~m}$. north of the moon.

On the first of the month Jupiter rises at 3 h. $19 \mathrm{~m}$. and crosses the meridian at $9 \mathrm{~h}$. $20 \mathrm{ml}$. A. M. On the last of the month Jupiter rises at $1 \mathrm{~h} .48 \mathrm{~m}$. and crosses the meridian at 7 h. 44 m. A. M.

The right ascension of Jupiter on the fifteenth day of the month is $12 \mathrm{~h} .14 \mathrm{~m} .37 \mathrm{~s}$. and its declination south 0 deg. $20 \mathrm{ml} .0 \mathrm{~s}$.

SATURA

Saturn is evening star throughout the greater part of the month. On November 25, at 1 hour, Saturn comes into conjunction with the sun, and changes to mornin star, but is too near the sun to be visible.

On the first of the month Saturn crosses the meridian at $1 \mathrm{~h} .10 \mathrm{~m}$. and sets at $6 \mathrm{~h} .3 \mathrm{~m}$. P. M. On the last of the month it rises about 20 minutes before the sun and crosses the meridian at $11 \mathrm{~h} .27 \mathrm{~m}$. A. M. The right ascension of Saturn on the fifteenth day of 1 series of very concordant experiments give the number
the month is $16 \mathrm{~h} .1 \mathrm{~m} .43 \mathrm{~s}$. and its declination south : $24: 362$ as the atomic weight of magnesium when oxygen $18 \mathrm{deg} .54 \mathrm{~m} .22 \mathrm{~s}$.
Uranuscomes into conjunction with the sun on Noember 21 , at 3 hours, and is therefore invisible. Neptune is approaching opposition to the sun, but does not telescopic observation before midnight.

The right ascension of Neptune on the seventeenth day of the month is $5 \mathrm{~h} .24 \mathrm{~m} .47 \mathrm{~s}$. and its declination the throughout the month.

inima of the variablestar. lows in Greenwich mean time :

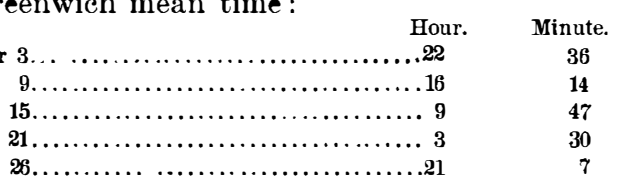

Only alternate minima are given above. Others Smith Observatory, Geneva, N. Y., October, 1897

$$
\text { science Notes. }
$$

Moseow, in honor of the medical congress just held person who has done eminent service to medical
pere $\$ 1,000$ for a prize to be awarded to some science during this generation. On Prof. Virchow's Dunant, founder of the Red Cross Society, who is living in great poverty in Switzerland. whatever its composition may be, has been used for success, according to the Lancet. Dr. De Renzi, for twenty-nine years professor of clinical medicine in the Naples University, reports forty-four cases of cure by tice, when in his hospital cases, while in private pracnot so far advanced in the disease when they first come to the doctor, the results are much better. $\mathrm{Dr}$. De Renzi has found no remedy for consumption superior to this serum.

The German papers record the death of Dr. Hans years as pupil in an "apotheke" in Salzwedel, and even years as pupil in an "apotheke" in Salzwedel, and even whing that period commenced the literary work by
which he afterward became famous. In recognition of the merit of his various publications he was excused his carried on with the assistance of a pupil for seventeen years. He then removed to Berlin and devoted himnection with pharmacy. The number of works he produced was very considerable, and several of them were translated into various languages. His services in other countries, and at the time of his death he was an honorary member of thirteen pharmaceutical societies.

To facilitate the study of $X$ rays, A. Imbert and $H$. Bertin-Sans had a special kind of "photometer" consists essentially of a fluorescent screen over which is laid a coarse grating of lead wires and a prism of aluminum. When the $\mathrm{X}$ rays examined are feeble, they are only able to penetrate the thin end of the prism,
and no shadows of lead wires are visible on the screen and no shadows of lead wires are visible on the screen
except under the thin end. This happens when the vacuum tube is exhausted just enough to give X rays. As exhaustion proceeds more lead wires become visible, and when the tube is on the point of becolling nonscreen is uniform, and the shadows stand out with equal sharpness. At this stage, indeed, aluminum becomes perfectly transparent to the rays, and so do cularly well suited for the radiography of the parti seated anatomy.-Comptes Rendus.

The atomic weight of magnesium has recently been appears in the current numbers of the Proceedings of the American Academy of Sciences. The previous eterminations of the atomic weight of this element howed a remarkable inconsistency until the year 1884 hen Marignac recorded the results of a large number of closely coneordant experiments pointing to the
number 24.37 . The accuracy of this number has now been confirmed by Messrs. Richards and Parker. The method selected, says Nature. was the analysis of mag nesium chloride. The salt was prepared, with great monium chloride by heating in a current of dry hydro en chloride; it was then transferred to a weighin tube, without the possibility of contact with moisture and the chlorine precipitated by silver nitrate, eithe $l$ is taken as 16.00 or $24 \cdot 179$ if oxygen be taken as 15.88 . ay be found by using the interval 2 days $20 \mathrm{~h} .49 \mathrm{~m}$

Dr. Maragliano's serum for pulmonary phthisis, Hermann Julius Hager at the advanced age of eightyassistant examination. On passing his qualifying ex-
amination he took a busines at Fraustadt, which he Mr. Parker, of with great care by Prof. Richards and
A SCOTTISH BUILT FERRY BOAT FOR NOVA SCOTIA. BY A. J. SINCLAIR.

On Sunday morning, August 15, the new ferry boat Chebucto left Gourock Bay, Scotland, for Halifax. The vessel returned to Gourock Bay on the forenoon of of weathe having put back from sea owing to the stress her journey when the captain deemed it advisable to put back, as the crew did not wish to go any further with the vessel, and, owing to the bad weather and a prevailing adverse wind, he was justified in returning to the Clyde.

The Dartmouth Ferry Commissioners. of Halifax, Nova Scotia, sent out offers toward the end of last year for the construction of a ferry steamer, and it was after keen competition with United States, Canadian, and other shipbuilders that Messrs. John Shearer \& Son, Kelvinhaugh Slip Dock, Glasgow, secured the contract to build the vessel. The Chebucto is a vessel of about 600 tons gross and is of a novel type. Both ends are alike, and at each end there is a screw propeller and rudder. The underwater body and ends of the vessel are yacht like in finemess. She was built for vessel are yacht like in fineness. She was built for
special goods and passenger ferry traffic bet ween Dartmouth and Halifax, Nova Scotia.

She is of the following dimensions: Over-all length, 40 feet; between perpendiculars, 125 feet; breadth extreme, 50 feet; breadth moulded, 33 feet; with a moulded depth of 13 feet 7 inches. The main body is constructed of steel to Lloyds highest class, with heavy deck beams, supported by longitudinal truss channel girders, each side of the vessel, for cart and carriage traffic. ers, each side of the vessel, for cart and carriage traffic.
These beams are carried out in one length to extreme These beams are carried out in one length to extreme
width of vessel, forming the sponson deck. The wings width of vessel, forming the sponson deck. The wings
are part of the integral structure, being supported by the outward sweep of the ship's frame and shell plating. On these wings are two spacious houses, each a bou t 100 feet long by $101 / 2$ feet wide by 13 feet high, seated all round with handsome curve back settee chairs, divided by electroplated elbows, affording seating accommodation for 222 passengers.

The wood work of the house is a combination of cherry wood and yellow pine. There are two tiers of windows in the sides, the upper tier being filled in with cathedral glass.

The ornament is very chaste, a fine effect being produced by the introduction of a light band of linerusta f elegant floral festoon design.

In the center of the vessel a monitor's house is built the whole length of the machinery space, for light and air to the engine room and access to the hurricane deck, the continuation of which to sides forms roofs of side houses. On the hurricane deck two pilot houses (one at each end) are placed, containing steering gear for each end of the ship. Extending over the hurricane deck and embracing pilot houses a light awning deck is fitted, shading a very commodious arrangement of deck seats of elegant construction. A complete instalation of electric lighting has been fitted throughout the pendent electroliers being very handsome. The cabins are heated by a thorough system of steam radiat rs. The Chebucto is rather a novel vessel, being of thing built in Britain like her before. In the mahinery department the vessel is quite as novel. The engines were supplied by Messrs. McKie \& Baxter Copeland Works, Govan, Glassow, and consist of two Copeland Works, Govan, Glasgow, and consist of two
pairs of double compound surface condensing engines, the sizes of the cylinders being 12 and 24 inches in diameter, with a piston stroke of 18 inches.

Steam is supplied at a working pressure of 125 pound by two Admiralty type boilers (each 7 feet 6 inches in diameter by 18 feet long), each having two of Fox's corrugated furnaces. The boilers were supplied by Messrs. A. Nicholson \& Company, Glasgow. There is an in stallation comprising five pumps, by the Blake \& Knowles Steam Pump Works (Limited), including Knowles Steam Pump Works (Limited), including a
duplex independent air pump, the first of its kind which has been fitted to a vessel in Britain, a special form of feed pump, a donkey pump, a boiler circulat ing pump and a sanitary pump. Hancock's inspirator re fitted for feeding the boilers and Hancock ejectors for cleaning the bilges. The air pump discharges into a tank from which the feed draws through a filter, the speed of this pump being automatically controlled by float. The exhaust steam for all the auxiliary enines is carried to the condenser, and the feed water passes through a heater on its way to the boilers. The centrifugal circulating pump was made by Messrs. McKie \& Baxter, is one of their "Challenge" patterns, and has a special balanced valve, the invenion of Mr. Baxter. The engines are reversed by direct acting steam gear upon an entirely new principle, tre invention of Mr. Baxter and Mr. D. B. Donald, of Fa mouth, and for which provisional protection has been secured. The boilers supply steam to an electric light engine and to the heating appliances throughout the vessel. In all there are thirteen separate engines in he engine room

The Chebucto was launched at Glasgow on the of June, and it was not until the 12th of August* -The illustration sent showsher on the trial trip day. 